\title{
ANALISIS FAKTOR RESIKO FILARIASIS \\ DI WILAYAH KERJA PUSKESMAS NGEMPLAK KABUPATEN BOYOLALI JAWA TENGAH
}

\author{
Athanasia Budi Astuti, Sri Mulyanti \\ Poltekkes Kemenkes Surakarta Jurusan Keperawatan
}

\begin{abstract}
Background: Currently filariasis is one of the priority diseases to be eliminated. WHO in 2000 declared the Global Goal of the Elimination of Lymphatic Filariasis as a Public Health Problem by the Year 2020. The Indonesian government's policy is to gradually implement Filariasis Elimination Program through Filariasis Provision of Mass Drug Prevention (POPM) programs in filariasis-endemic districts / cities and management of filariasis clinical cases. Filariasis cases in Central Java in 2013 - 2016 tended to increase, including in Boyolali Regency. If this condition is not immediately treated properly, it can make it possible to end up with filariasis. Methods: Materials and methods. This research is a survey research with mixedresearch or mixed research approach. Respondents were patients and families of filariasis sufferers, government stakeholders, and health stakeholders. Data was obtained through in-depth interviews, focus group discussions, and field observations. Results: Filariasis risk factors found were (1) lack of knowledge of patients and families about the treatment and prevention of transmission of filariasis (2) mosquito vector control has not been done well (3) Home environment conditions (3) Still found gaps or gaps between health sector stakeholders (4) There are still filariasis patients who have not carried out filariasis treatment properly. Conclusion: Risk factors for filariasis are individual factors, lack of efforts to control mosquito vectors, environmental factors, and the existence of gaps between health stakeholders.
\end{abstract}

Keyword: Risk Factors, Filariasis, Filariasis Patients, Stakeholder

\section{PENDAHULUAN}

Faktor utama yang mendorong penelitian ini adalah semakin meningkatnya angka kejadian filariasis di Kabupaten Boyolali. Sedangkan tindakan pengendalian filariasis membutuhkan data faktor resiko filariasis sesuai karakterisitik wilayah. Sedangkan di Kabupaten Boyolali belum ada penelitian tentang faktor resiko filariasis. Saat ini penyakit filariasis telah menjadi salah satu penyakit yang diprioritaskan untuk dieliminasi. Hal ini diperkuat dengan keputusan WHO pada tahun 2000 yang mendeklarasikan
The Global Goal of Elimination of Lymphatic Filariasis as a Public Health Problem by the Year 2020. ${ }^{1}$

Hingga pada tahun 2015, situasi program eliminasi filariasis yaitu dari 514 kabupaten/ kota di Indonesia terdapatnya 239 kabupaten/ kota endemis filariasis, hanya 132 kabupaten/ kota yang melaksanakan POPM Filariasis dan masih ada 58 kabupaten/ kota endemis yang belum melaksanakan POPM filariasis dikarenakan berbagai kendala. Terdapat 48 kabupaten/ kota telah selesai melaksanakan POPM filariasis selama 5 
tahun berturut-turut, akan tetapi hanya 26 kabupaten/ kota yang lulus tahap evaluasi (TAS) dan 22 kabupaten/ kota gagal dalam tahap evaluasi, sehingga harus melaksanakan POPM tambahan selama 2 tahun berurut-turut untuk selanjutnya dilakukan evaluasi kembali (Depkes RI, 2010). ${ }^{2}$ Kasus Filariasis di Jawa Tengah pada tahun 2013 - 2016 terdapat di 20 Kabupaten yaitu Kota Semarang, Surakarta, Pekalongan, Pati, Brebes, Jepara, Magelang, Kebumen, Demak, Wonogiri, Grobogan, Kendal, Boyolali, Batang, Sukoharjo, Blora, Wonosobo, Sragen, Banjarnegara. Kasus Filariasis ini tiap tahun mengalami peningkatan dari 10 kasus menjadi 22 kasus, kemudian meningkat lagi menjadi 27 kasus. Penemuan kasus terbaru pada tahun 2016 di Jawa Tengah adalah di Demak 14 kasus, Boyolali 4 kasus, Kota Semarang 3 kasus, Brebes 2 kasus, dan yang Kota lainnya masing - masing 1 kasus yaitu di Wonogiri, Grobogan, Sukoharjo, Banjarnegara

Upaya pemberantasan filariasis tidak bisa dilakukan oleh pemerintah semata, peran masyarakat melalui kader kesehatan dan tokoh masyarakat sangat dibutuhkan. Berdasar penelitian-peneitian tersebut di atas, upaya eliminasi filariasis membutuhkan data-data faktor resiko yang ada di wilayah masing-masing sehingga dapat dilakukan upaya perbaikan. Padahal di wilayah Kecamatan Ngemplak Boyolali belum pernah dilakukan survey atau penelitian tentang faktor resiko yang dapat meningkatkan resiko terjadinya lariasis. Penelitian ini berusaha mencari data-data tentang faktorfaktor resiko filariasis di wilayah Kecamatan Ngemplak Boyolali. Melalui penelitian ini diharpakan dapat diketahui faktor resiko yang ada dimasyarakat, faktor pendukung dari pemerintahan, dan bidang kesehatan yang dapat dipakai sebagai dasar upaya eliminasi filariasis.

\section{METODE PENELITIAN}

Penelitian dilakanakan mulai bulan Januari sampai bulan Oktober 2018. Penelitian berupa penelitian kombinasi kuantitatif dan kualitatif (study mixed research). Bertujuan mengetahui faktor resiko filariasis di wilayah kerja Puskesmas Ngemplak Kabupaten Boyolali. Data diperoleh dari pasien dan keluarga, stakeholder bidang kesehatan dan pemerintahan melalui wawancara mendalam, FGD, dan observasi lapangan. Data dianalisis secara kuantitatif dan kualitatif (mixed research)

\section{HASIL PENELITIAN}

Tabel 1. Karaktersitik Pasien Filariasis di Puskesmas Ngemplak Boyolali

\begin{tabular}{ccc}
\hline Kategori & f & \% \\
\hline Umur & & \\
$20-30$ & 0 & 0 \\
$31-40$ & 0 & 0 \\
$41-50$ & 5 & 83,33 \\
$>50$ & 1 & 16,67 \\
Pendidikan & & \\
SD & 5 & 83,33 \\
SMP & 0 & 0 \\
SMA & 1 & 16,67 \\
Diploma & 0 & 0 \\
Sarjana & 0 & 0 \\
Tinggal Serumah & & \\
Ya & 6 & 100 \\
Tidak & 0 & 0 \\
Status & & \\
Janda & 0 & 0 \\
Duda & 0 & 0 \\
\hline Jumlah responden pasien
\end{tabular}

Jumlah responden pasien filariasis adalah 7 (tujuh) pasien, dimana 6 (enam) pasien masih hidup dan 1 (satu) pasien sudah meninggal dunia. Tabel 4.1. memberikan gambaran dari segi umur paling banyak pada ketegori umur $41-50$ tahun sebanyak $83,33 \%$, tingkat 
pendidikan paling banyak pada pendidikan dasar (SD) 83,33\%, semua $(100 \%)$ pasien saat ini tinggal serumah keluarga dan berdasar status perkawinan, semua pasien masih hidup dengan pasangan masing-masing (suami atau istri).

Tabel 2. Riwayat Pengobatan Pasien Filariasis (Kode:R-PK)

\begin{tabular}{lcc}
\hline Kategori & $\mathbf{f}$ & $\%$ \\
\hline Pengobatan (Minum Obat) & \\
Ya & 3 & 42,86 \\
Tidak & 4 & 57,14 \\
Pengetahuan Pasien dan Keluarga & tentang \\
Pedoman Pengobatan Filariasis & \\
$\quad$ Tahu & 3 & 42,86 \\
$\quad$ Tidak Tahu & 4 & 57,14 \\
Status Kesehatan (Hidup) & & \\
$\quad$ Hidup & 6 & 85,71 \\
$\quad$ Meninggal & 1 & 14,29 \\
\hline
\end{tabular}

Tabel 2. menunjukkan responden yang masih aktif melakukan pengobatan adalah 3 pasien atau 42,86\%. Sedangkan yang tidak lagi mengkonsumsi obat lebih banyak yaitu $57,14 \%$ dengan berbagai macam kendala. Tabel 2. juga memberikan gambaran masih ada 57,14\% pasien dan atau keluarga yang tidak mengetahui cara mengkonsumsi obat filariasis, dimana pasien dan keluarga tidak tahu nama obat yang diminum, belum mengetahui pedoman atau atau cara minum obat

Tabel 3. Distribusi Stakeholder

\begin{tabular}{lcc}
\hline \multicolumn{1}{c}{ Stakeholder } & f & \% \\
\hline Pemerintah & 11 & 26,67 \\
Kecamatan (1) & 1 & \\
Lurah (2) & 5 & \\
Tokoh Masyarakat (3) & 5 & \\
Kesehatan & 19 & 63,33 \\
Dinas Kesehatan (1) & 6 & \\
Puskesmas (2) & 5 & \\
Kader Kesehatan (3) & 4 & \\
SKD (4) & 4 & \\
\hline Jumlah & $\mathbf{3 0}$ & $\mathbf{1 0 0}$ \\
\hline
\end{tabular}

Tabel 3. Menunjukkan jumlah responden dari stakeholder berjumlah 30 yang terdiri dari unsur pemerintahan $26,67 \%$ dan dari bidang kesehatan sebanyak $63,33 \%$.

Tabel 4. Distribusi Frekwensi Faktor Resiko Filariasis Terkait Host (Manusia)

\begin{tabular}{llc}
\hline Faktor Resiko & f & $\%$ \\
\hline Riwayat Keluarga & & \\
Ada & 0 & 0 \\
Tidak & 7 & 100 \\
$\begin{array}{ll}\text { Pekerjaan (Sering } \\
\text { Rumah) }\end{array}$ & \multicolumn{2}{c}{} \\
Ya & 7 & 100 \\
Tidak & 0 & 0 \\
Tingkat Pendidikan & & \\
Dasar & 6 & 85,71 \\
Menengah & 1 & 14,29 \\
Tinggi & 0 & 00,00 \\
\hline
\end{tabular}

Sesuai tabel 4. faktor resiko penyakit filariasis untuk semua pasien termasuk yang sudah meninggal, sesuai hasil kuesioner dan wawancara dengan paisen dan keluarga pasien diperoleh informasi bahwa faktor resiko filariasis terkait dengan host (manusia) meliputi sering berada di luar rumah tanpa pelindung dari gigitan nyamuk (100\%) dan tingkat pendidikan yang masih rendah atau pendidikan kurang, dimana tingkat pendidikan atau lulusan SD $85,71 \%$ dan yang berpendidikan menengah 14,29\% .

Tabel 5. Distribusi Frekwensi Hasil Observasi Karakteristik Lingkungan sebagai Faktor Resiko Filariasis

\begin{tabular}{lcc}
\hline \multicolumn{1}{c}{$\begin{array}{c}\text { Karakteristik } \\
\text { Lingkungan }\end{array}$} & Ya & Tidak \\
\hline Keberadaan kawat & 0 & 7 \\
kasa & $(00,00)$ & $(100)$ \\
Keberadaan saluran & 4 & 3 \\
limbah & $(57,14)$ & $(42,86)$ \\
Keberadaan semak- & 5 & 2 \\
semak vektor & $(71,43)$ & $(28,57)$ \\
Keberadaan & 5 & 2 \\
nyamuk & $(71,43)$ & $(28,57)$ \\
\hline
\end{tabular}


Karakterisitik lingkungan sebagai faktor resiko penyakit filariasis, berdasar observasi langsung ke rumah pasien filariasis baik yang masih hidup, maupun yang sudah meninggal menunjukkan resiko digigit nyamuk sangat tinggi. Hal ini terlihat dari $100 \%$ atau semua rumah dan kamar tidur pasien tidak dipasang sarana pencegah masuknya nyamuk, padahal 57,14\% lingkungan rumah pasien terdapat saluran pembuangan air (got atau kalen) dengan aliran air tidak lancar atau menggenang, $71 \%$ di sekitar rumah pasien terdapat semak-semak tempat nyamuk hidup dan berkembang biak, dan $71 \%$ rumah pasien terdapat banyak nyamauk pada malam hari dang menjelang dini hari (pukul 21.00-03.00 WIB).

Tabel 6. Distribusi Frekwensi Faktor Resiko Filariasis Terkait Upaya Pencegahan Penularan

\begin{tabular}{|c|c|c|}
\hline $\begin{array}{c}\text { Kondisi/Upaya } \\
\text { Pencegahan }\end{array}$ & Ya & Tidak \\
\hline $\begin{array}{l}\text { Keberadaan } \\
\text { kelambu }\end{array}$ & $\begin{array}{c}0 \\
(00,00)\end{array}$ & $\begin{array}{c}7 \\
(100)\end{array}$ \\
\hline $\begin{array}{l}\text { Menggunakan obat } \\
\text { nyamuk }\end{array}$ & $\begin{array}{c}0 \\
(00,00)\end{array}$ & $\begin{array}{c}7 \\
(100)\end{array}$ \\
\hline $\begin{array}{l}\text { Keberadaan kawat } \\
\text { kasa }\end{array}$ & $\begin{array}{c}0 \\
(00,00)\end{array}$ & $\begin{array}{c}7 \\
(100)\end{array}$ \\
\hline $\begin{array}{l}\text { Kebiasaan di luar } \\
\text { rumah }\end{array}$ & $\begin{array}{c}3 \\
(42,86)\end{array}$ & $\begin{array}{c}4 \\
(57,14)\end{array}$ \\
\hline $\begin{array}{l}\text { Kebiasaan memakai } \\
\text { baju/celana panjang }\end{array}$ & $\begin{array}{c}3 \\
(42,86)\end{array}$ & $\begin{array}{c}4 \\
(57,14)\end{array}$ \\
\hline $\begin{array}{l}\text { Keberadaan semak- } \\
\text { semak }\end{array}$ & $\begin{array}{c}6 \\
(85,71)\end{array}$ & $\begin{array}{c}1 \\
(14,29)\end{array}$ \\
\hline $\begin{array}{l}\text { Kebiasaan } \\
\text { membersihkan } \\
\text { semak-semak }\end{array}$ & $\begin{array}{c}2 \\
(28,57)\end{array}$ & $\begin{array}{c}5 \\
(71,43)\end{array}$ \\
\hline $\begin{array}{l}\text { Keberadaan saluran } \\
\text { pembuangan air } \\
\text { limbah }\end{array}$ & $\begin{array}{c}6 \\
(85,71)\end{array}$ & $\begin{array}{c}1 \\
(14,29)\end{array}$ \\
\hline $\begin{array}{l}\text { Kebiasaan } \\
\text { membersihkan } \\
\text { saluran } \\
\text { pembuangan air } \\
\text { limbah }\end{array}$ & $\begin{array}{c}2 \\
((28,57)\end{array}$ & $\begin{array}{c}5 \\
(71,43)\end{array}$ \\
\hline
\end{tabular}

Tabel 6. menunjukkan semua pasien $(100 \%)$ tidak menutup kamar tidur dengan kelambu, termasuk di sini adalah tidak menutup atau memakai kawat kasa pada ventilasi rumah untuk mencegah masuknya nyamuk ke kamar tidur atau ke dalam rumah. Selain itu semua pasien yang terdiagnosa filariasis juga tidak memakai obat nyamuk saat tidur. Terkait kebiasaan sering berada di luar rumah (kebun, halaman, gang/jalan dll) pada malam hari (pukul 21.00 - 03.00) mayoritas atau $57,14 \%$ responden sering melakukan hal tersebut dan 42,86\% jarang. Data yang sama diperoleh untuk kebiasaan responden memakai pakaian atau obat untuk mencegah digigit nyamuk saat berada di luar rumah, yaitu $57,14 \%$ jarang atau tidak pernah dan hanya $42,86 \%$ yang terbiasa memakaianya. Keberadaan semak-semak sebagai tempat hidup dan berkembang biaknya nyamuk filarasis $85,71 \%$ ada dan hanya 14,29 yang tidak ada. Namun sayangnya hanya $28,57 \%$ yang terbiasa membersikannya, sedangkan 71,43 jarang atau tidak pernah membersihkan semak-semak di sekitar rumah.

\section{PEMBAHASAN \\ Faktor Resiko Terkait Host}

Peraturan Menteri Kesehatan (PMK) Republik Indonesia No. 94 tahun 2014 tentang penanggulangan Filariasis, patologi dan penularan Filariasis menjelaskan bahwa epidemi penyakit filariasis dipengaruhi oleh faktor karakteristik manusia. Manusia sebagai individu merupakan ciri-ciri yang dimiliki oleh seseorang yang berhubungan dengan semua aspek kehidupan dengan lingkungannya, baik faktor biologis seperti genetik, sistem syaraf dan hormonal, ataupun faktor 
sosiopsikologis seperti kognitif (intelektual), konatif (kebiasaan dan kemauan bertindak), maupun afektif (emosional). Tingkat pendidikan dasar (SD) secara umum mempengaruhi tingkat kognitif atau intelektual pasien, termasuk dalam memahami konsep penyakit filariasis. Hal ini terbutki walaupun sebagain besar pasien filariasis dan keluarga mengatakan sudah pernah memperoleh penjelaan tentang penyakit filariasis, namun dalam praktinya belum menunjukkan pemahaman yang cukup. Hal ini dibuktikan dengan hasil diskusi dan wawancara mendalam dengan pasien dan keluarga dengan data sebagai berikut "Saya dan suami saya tidak tahu kalau terkena penyakit filariasis, karena awalnya kaki hanya terasa gatal kok kemudian bertambah besar. Penyakit ini hanya saya yang mengalami, sedang bapak, ibu, ataupun yang lain tidak ada yang sakit seperti ini" ( $R-P K)$

"Saya sudah malas minum obat, biarlah yang sakit kan ya saya sendiri. Lha wong minum obat terus ya tida sembuh-sembuh. Saya sudah bosan Mbak" (R-K)

Praktik pengobatan filariasis yang dilakukan oleh responden kurang komprehensif sesuai pedoman yang ada. Padahal salah satu faktor yang mempengaruhi keberhasilan program eliminasi filariasis adalah faktor manusia seperti kepatuhan minum obat. "Terus terang kami belum begitu paham tentang cara minum obat kaki gajah, harus berapa lama dan sampai kapan. Yang penting bila obat habis, saya datang ke puskesmas untuk kontrol" (R-PK)

Ungkapan tersebut membuktikan pasien dan keluarga belum memahami bagaimana cara minum obat filariasis yang tepat. Jika pasien tidak minum obat dengan baik dan paripurna, maka resiko menularkan ke orang lain cukup besara. Aapalagi ditambah perilaku pengendalian vektor nyamuk juga belum dilakukan dengan baik. "Saya memang sudah tidak minum obat lagi, karena sudah tidak diberi dari Puskesmas, untuk beli sendiri juga tidak punya uang, maka saya berhenti minum obat. Petugas kesehatan juga tidak mengontrol dengan ketat, sehingga saya juga kadang males, apalagi keluarga kadang juga cuek" (R-PK)

Faktor petugas kesehatan dan keluarga ternyata juga mempengaruhi kepatuhan pasien minum obat. Hal ini sesuai dengan penelitian Astuti dkk pada tahun 2013 tentang pengaruh perilaku masyarakat terhadap kepatuhan minum obat POMP di Kec. Majalaya Kab. Bandung, yang membuktikan bahwa kepatuhan minum obat pada pasien filariasis dipengaruhi oleh petugas kesehatan, kader kesehatan, kerjasama lintas sektoral, dan media promosi kesehatan. $^{3}$

Data tersebut kurang sesuai dengan apa yang pernah diupayakan petugas kesehatan dalam mendorong pasien minum obat. Hasil penelitan Ipa, Mara dkk (2016) menujukkan upaya peningkatan kepatuhan minum obat dapat dilakukan dengan teknik pemberian informasi dampak negatif akibat efek samping obat, peningkatan jumlah dan pengetahuan kader serta peningkatan kegiatan monitoring pelaksanaan pengobatan. Peningkatan cakupan pengobatan juga pernah dilakukan melalui pencanangan minum obat ditempat dengan pemberdayaan tenaga kader. $^{4}$ Penelitian Krentel dkk (2013) tentang faktor-faktor yang mempengaruhi pengobatan filariasis dengan program MDA juga memberikan bukti bahwa keberhasilan MDA sangat dipengaruhi 
pleh peran petugas kesehatan dan masyarakat secara umum.Hasil penelitian yang hampir sama adalah dari penelitian Kumar, Anil (2014) tentang peran masyarakat dalam cakupan pengobatan MDA yang membuktikan bahwa keberhasilan eliminasi limfaktik filariasis dengan program MDA perlu peningkatan peran masyarakat karena MDA harus dilakukan dalam waktu yang lama dan kontinyu. ${ }^{6}$

Selain itu pasien dan keluarga juga belum melakukan upaya pencegahan penularan penyakit filariasis secara baik. Hal ini sesuai dengan hasil penelitian Agustianingsih (2013) yang juga menunjukkan karakterisitik inividu yang mempunyai hubungan dengan praktik pencegahan filariasis yaitu tingkat pendidikan $(\mathrm{p}=0,041)$, jenis pekerjaan $(\mathrm{p}=$ $0,047)$, tingkat pengetahuan $(\mathrm{p}=0,000)$, sikap $(\mathrm{p}=0,000)$, persepsi $(\mathrm{p}=0,000)$.

Dilihat dari keberadaan pasien saat ini semua pasien atau $100 \%$ tinggal serumah dengan pasangan (istri atau suami) dan tinggal dalam keluarga bersama anggota keluarga yang lain yaitu anak dan atau menantu. Berdasarkan status perkawinan, semua pasien masih hidup dengan pasangan masing-masing (suami atau istri). "Saya dan suami saya tidak tahu kalau terkena penyakit filariasis, karena awalnya kaki hanya terasa gatal kok kemudian bertambah besar. Penyakit ini hanya saya yang mengalami, sedang bapak, ibu, ataupun yang lain tidak ada yang sakit seperti ini" $(R-P K)$

Berdasar wawancara mendalam dengan anggota keluarga seperti tersebut di atas, membuktikan tidak ditemukan riwayat anggota keluarga terdahulu yang mempunyai penyakit atau gejala penyakit yang sama. Data ini menunjukkan tidak ada faktor resiko genetik pada pasien filariasis di wilayah kerja Puskesmas Ngemplak Boyolali.

\section{Faktor Resiko Terkait Perilaku}

Perilaku kesehatan dipengaruhi oleh beberapa faktor yang secara langsung maupun tidak langsung akan membentuk tindakan dan kebiasaan individu (Notoatmodjo, 2010). Sesuai konsep rantai infeksi, penyakit infeksi dapat menular dipengaruhi oleh tiga komponen, yaitu agent, host, dan environment (lingkungan). Demikian juga dengan penyakit filariasis, sumber penularan utama (hospes reservoir) penyakit ini adalah manusia yang mengandung mikrofilaria dalam darahnya. Pada dasarnya setiap orang dapat tertular filariasis apabila digigit oleh nyamuk infektif (mengandung larva stadium 3). Faktor resiko filariasis terkait perilaku yang ditemukan pada penelitian ini adalah kebiasaan sering berada di luar rumah (kebun, halaman, gang/jalan dll) pada malam hari (pukul 21.00 - 03.00). Hasil wawancara dengan pasien dan keluarga diperoleh data bahwa sebelum terjangkit penyakit filariasis, mayoritas atau $57,14 \%$ responden sering atau terbiasa melakukan kegiatan atau aktivitas di luar rumah seperti begadang (jagongan) di kebun, halaman, gang/jalan dll. Hal ini dilakukan hampir setiap malam, karena sekedar mengisi waktu. Selain itu karena kamar tidur juga tidak ditutup kelambu, dan tidak ada kawat kasa pada ventlasi rumah sangat memugkinkan nyamuk dapat masuk ke rumah pada malam sampai dini hari. Hal ini diperkuat dengan hasil wawancara mendalam "Saya memang sering keluar rumah pada malam hari, karena untuk jagongan dan saya memang senang begadang di halaman dan jalan 
dekat kampung. Saya biasanya masuk rumah kalau sudah mulai ngantuk, sekitar jam 12 atau jam 01 malam, kadang malah lebih". (R-PK)

Kebiasaan ini meningkatkan resiko terkena atau menularkan penyakit filariasis, karena secara daur hidup larva filariasis akan berada pada pembuluh dara tepi pada malam sampai dini hari pada waktu tidak ada sinar matahari. "Saya kurang begitu paham tentang cara penularan penyakit kaki gajah, yang saya tahu katanya oleh nyamuk. Tapi saya dan keluarga memang jarang perhatian dengan kebersihan lingkungan. Maklum kami kan keluarga tidak punya, sehingga waktunya ya dipakai untuk cari rejeki. Apalagi untuk beli kelambu dan pasang jaring kasa, untuk beli beras dan gula saja kadang kurang". (R-PK)

Faktor resiko lain terkait perilaku manusia adalah kurangnya kebiasaan membersihkan semak belukar yang ada di sekitar rumah. Sesuai hasil penelitian terlihat keberadaan semak-semak sebagai tempat hidup dan berkembang biaknya nyamuk filarasis $85,71 \%$ ada dan hanya 14,29 yang tidak ada. Namun sayangnya hanya 28,57 \% yang terbiasa membersikannya, sedangkan 71,43 jarang atau tidak pernah membersihkan semaksemak di sekitar rumah. Hasil atau angka yang sama adalah pada kategori keberadaan saluran air (got) yang airnya menggenang di sekitar rumah. Dari seluruh pasien, $85,71 \%$ di sekitar rumahnya ada saluran pembuangan limbah air (got atau kalen) dengan air yang tidak lancar (menggenang), hanya $28,57 \%$ yang sering membersihkannya.

\section{Karakterisitik Lingkungan sebagai Faktor Resiko Filariasis}

Di luar rumah, nyamuk juga suka beristirahat pada kandang ternak karena suhu kelembaban kandang ternak sangat cocok untuk nyamuk. Hasil penelitian Setiani dan Hanani (2012) menunjukkan tempat istirahat nyamuk sebagai vektor filariasis barada di semaksemak, kandang ternak, pakaian yang digantung. Hasil analisa univariat menunjukkan bahwa proporsi kejadian filariasis pada kelompok kasus lebih besar pada kelompok kasus yang memiliki tempat istirahat nyamuk $(68,8 \%)$ dibandingkan pada kelompok kontrol $(31,2 \%)$. Kondisi tersebut ditemukan pada saat penelitian dimana $100 \%$ atau semua rumah dan kamar tidur pasien tidak dipasang sarana pencegah masuknya nyamuk, padahal $57,14 \%$ lingkungan rumah pasien terdapat saluran pembuangan air (got atau kalen) dengan aliran air tidak lancar atau menggenang, $71 \%$ di sekitar rumah pasien terdapat semak-semak tempat nyamuk hidup dan berkembang biak, dan $71 \%$ rumah pasien terdapat banyak nyamuk pada malam hari dang menjelang dini hari (pukul 21.00 03.00 WIB. Kondisi tersebut memungkinkan resiko untuk digigit nyamuk secara berulang sangat tinggi. Hasil wawancara secara lebih mendalam, diperoleh data kondisi tersebut sudah ada sebelum pasien terdiagnosa filariasis, sehingga dapat dianalisis kalau faktor lingkungan yang ada pada pasien dapat meningkatkan resiko terkena penyakit filariasis. Di sisi lain, kondisi lingkungan pasien filariasis saat ini juga sangat memungkinkan terjadinya resiko penularan filariasis ke orang lain.

\section{Peran Stakeholder Pemerintahan}

Hasil penelitian melalui Focus Group Discussion (FGD) dapat disimpulkan stakeholder pemerintahan 
melalui perwakilan kecamatan, babinkamtibmas, dan kepala desa, serta tokoh masyarakat, dapat disimpulkan secara umum sudah mengetahui tentang penyakit filariasis yaitu penyakit kaki gajah yang disebabkan oleh nyamuk. Sepakat bahwa penyakit filariasis masih ada di wilayah Puskesmas Ngemplak Boyolali, tetapi jarang atau hanya sedikit. Walaupun jumlah pasien relatif sedikit, namun penyakit ini sangat berbahaya dan bisa menular. "Penyakit filariasis juga disebut penyakit kaki gajah. Penyakit ini masih ada di wilayah Puskesmas Ngemplak Boyolali, tetapi jarang atau hanya sediki. "Walaupun sedikit penyakit ini sangat berbahaya dan bisa menular". Penyebab penyakit ini diluar dugaan karena hanya oleh nyamuk. Untuk itu masyarakat sebaiknya mengetahui penyakit ini, supaya tidak terltular atau dapat melakukan pencegahan penyakit kaki gajah ".(R-P)

Data-data tersebut membuktikan bahwa secara umum sebenaranya pihak pemerintah desa baik dari kecmatan, kepala desa, maupun tokoh masyarakat sudah sedikit mengetahui tentang penyakit filariasis, bahakan sudah menydari kalau penyakit ini berbahaya dan dapat menular. Bahkan dari wawancara lebih jauh sudah mempunyai gagasan kalau masyarakat harus mengetahui penyakit ini. Namun data ini agak kontrakdiktif dengan tingkat pengetahuan dan pemahaman yang dimiliki oleh pasien dan keluarga, dimana mayoritas pengetahuan dan pemahamannya masih kurang. Di sisi lain persepsi stakeholder pemerintahan desa terhadap peran Puskesmas dalam pemberantasan penyakit kaki gajah juga sudah baik. "Selama ini Puskesmas sudah melaksanakan program pencegahan penyakit, yaitu dengan mengadakan sosialisasi atau penyuluhan kesehatan pada masyarakat". Kalau diadakan program peberantasan dan pencegahan penyakit, pemerintah kecamatan dan pemerintah desa sangat mendukung". (R$\mathrm{P})$

Berdasar uraian tersebut dapat dianalisa masih ada gap atau kesenjangan dalam hal pengetahuan, pemahaman, dan kesadaran tentang penanggulangan penyakit filariasis antara pasien dan keluarga dengan stakeholder pemerintahan. Dapat dimungkinkan hal ini terjadi karena pada saat penyuluhan kesehatan yang dilakukan pihak puskesmas, yang lebih mudah menerima dan memahaminya adalah pihak pemerintajan desa, sedangkan pasien dan keluarga belum mampu menerima dan memahaminya dengan baik. Hal ini juga terbukti dari harapan pemerintahan desa yang berpersepsi bahwa puskesmas harus lebih meningkatkan intensitas penyuluhan dan lebih sabar dalam membimbing masyarakat. "Puskesmas harus meningkatkan intensitas penyuluhan dan sosialisasi penyakit ini, supaya masyarakat lebih paham tentang penyakit filariasis, sehingga mampu melakukan upaya pencegahan timbulnya penayakit ini. Puskesmas harus lebih fokus dan sabar dalam membimbing masyarakat, sehingga bagi yang sudah terkena penyakit filariasis dapat diselamatkan". (R-P)

"Program pemerintah sudah baik, namun perlu ditingkatkan dan dioptimalkan lagi. Masih banyak masyarakat yang tidak mengetahui penyakit ini". (R-P)

Analisis dari pernyataan pihak pemerintahan tersebut adalah kepala desa dan tokoh masyarakat mungkin lebih sering kontak dengan pasien dan keluarga penderita filariasis, atau dari laporan 
masyarakat secara umum, sehingga lebih banyak menerima keluhan atau informasi dari masyarakat. Hal ini dibuktikan juga dari rangkuman saran yang diberikan oleh pihak pemerintahan yaitu "Peningkatan sosialisasi dan penyuluhan melalui bidan desa, kader kesehatan, dan tokoh masyarakat, meningkatkan gerakan kebiasaan hidup bersih dan sehat, melaksanakan kerjabakti/kebersihan desa secara berkala, memotivasi dan membimbing penderita untuk aktif berobat, diadakan pencegahan dini dengan gerakan bersama” ( $R-P)$

\section{Peran Stakeholder Kesehatan}

Hasil penelitian menunjukkan masih ada sedikit perbedaan konsep dalam pelaksanaan program penanggulangan penyakit filariasis. Masih ditemukan kesan program belum berjalan dengan baik. Pihak Dinas kesehatan selaku koordinator program mengharapkan Puskesmas sebagai unit pelaksana teknis harus lebih aktif dan proaktif, sedangkan dari pihak Puskesmas, merasa sudah melakukan program dengan baik. "Puskesmas sebagai ujung tombak atau garda terdepan dari peningkatan kesehatan masyarakat harus mampu bekerja dan melaksanakan program yang selaras dengan program dinas kesehatan. Selama ini memang sudah ada ada program deteksi dini filariasis, namun jangkaunya masih sangat kurang". "Selama ini Dinas Kesehatan Kabupaten Boyolali merasakan Puskesmas masih kurang fokus dalam penanganan penyakit filariasis, sehingga masih perlu mendapat pendampingan". (R-K DKK)

"Kami merasa sudah melaksanakan upaya pencegahan dengan melaksanakan program promotif atau penyuluhan kesehatan kepada masyarakat tentang penyakit filariasis dan penularanya. Puskesmas juga sudah melakukan surveilan epidemiologis, dengan melakukan pendataan penderita yang kemudian ditindaklanjuti dengan pemeriksaan laboratorium bekerjasama dengan Dinas Kesehatan Kabupaten Boyolali dan BPTK Yogyakarta”. (R-K PUSKESMAS)

Terkait dengan pelaksanaan program secara teknis juga masih ada mispersepsi antara dinas kesehatan dengan Puskesmas. "Saya berharap Puskesmas dapat melakukan pendataan atau pengkajian yang lebih komprehensif dan berkelanjutan. Bagi warga yang sampel darahnya sudah positip filariasis harus diobati dengan program DEC, dan keluarga serta masyarakat sekitarnya harus ditingkatkan pola hidup bersih dan sehatnya melalui pengaktifan program PHBS". (R-K DKK)

"Kami merasa sudah melakukan upaya pencegahan melalui sosialisasi penyakit dan penyuluhan kesehatan. Selain itu sudah berusaha melakukan pengkajian untuk menemukan penderita baru dengan pengambilan sampel darah, dan yang sudah positip kemudian segera diobati. Namun kendala yang dihadapi adalah respon masyarakat yang sangat bervariasi, yang kadang kurang sesuai dengan harapan petugas kesehatan. Contohnya pasien tidak mau diperiksa darahnya, tidak mau minum obat teratur, ada juga yang sudah bosan dan frustasi karena harus minum obat terus menerus". (R-K PUSKESMAS)

Terkait dengan persepsi terhadap peran pemerintah, juga masih ada perbedaan pendapat, yang walaupun tidak prinsip, namun juga dapat mengganggu proses penanggulangan filariasis. "Kami merasa peran pemerintah melalui dinas 
kesehatan sudah optimal, terutama dalam penyediaan obat, jika ada temuan kasus baru, dinas kesehatan langsung menurunkan tim ke lapangan untuk penanganan lebih intensif. Tinggal meningkatkan peran serta Puskesmas, tokoh masyarakat dan kader kesehatan. Terkadang Puskesmas dan masyarakat berpikir penyakit ini sudah tidak ada, sehingga perhatian dan kewasapadaan menjadi kurang”. (R-K DKK)

"Kami merasakan upaya pemerintah dalam pencegahan dan pengobatan filariasis belum begitu optimal, misalnya masih minimnya media informasi, ketersediaan obat masih kurang, sulitnya melakukan pemeriksaan laborat untuk menemukan penyakit dan sumber penularanya. Untuk itu diperlukan kerjasama yang kompak untuk bahu membahu memberantas penyakit filariasis". (R-K PUSKESMAS)

Persespi yang agak berbeda diperoleh dari kader kesehatan dan SKD, dimana mayoritas berpendapat bahwa peran Puskesmas sudah cukup baiak, namun perlu peningkatan lagi. "Kami merasa upaya Puskesmas dalam pencegahan filariasis sudah optimal, melalui penyuluhan kesehatan kepada warga, namun hasil akhir dikembalikan lagi kepada kesadaran warga”. Mungkin upaya pemeriksaan laborat pada warga untuk mendeteksi penyakit filariasis, perlu dilakukan lagi seperti dulu". Kami berharap seharusnya puskesmas mengadakan program deteksi dini dan memberikan obat cacing secara masal, minimal $2 x$ dalam setahun". Kami sependapat dan setuju, mestinya Puskesmas menfasilitasi deteksi dini, dan kami akan berupaya membantu". Peran Puskesmas sudah optimal, tapi perlu ditingkatkan dengan menambah tenaga kesehatan sampai ke pelosok-pelosok desa dan menambah jumlah kader kesehatan supaya lebih banyak informasi yang sampai ke warga dan dapat mengurangi kejadian penyakit filariasis".

Berdasar hasil penelitian tersebut menggambarkan bahwa masih ada gap atau kesenjangan yang terjadi antara Dinas Kesehatan, Puskesmas, dan pasien dal hal program pengobatan dan pencegahan (eliminasi) penyakit filariasis. Dinas kesehatan sebagai koordinator utama dari kementerian kesehatan (pemerintah) merasa sudah melaksanakan fungsi koordinasi dengan baik, namun disisi lain Puskesmas merasakan peran pemerintah dan dinas kesehatan masih kurang. Demikian juga Puskesmas merasa sudah melaksanakan program sosialisasi dan penyuluhan kesehatan kepada pasien dengan baik, namun pada kenyataanya pasien dan keluarga merasa belum diberikan pengetahuan atau penyuluhan secara lebih intensif, yang terbukti saat dilakukan wawancara dan kunjungan rumah pasien dan keluarga masih ada yang belum melakukan program pengobatan dan pencegahan penularan filariasis secara baik. Selain itu pasien, keluarga pasien, dan kader kesehatan juga belum begitu paham tentang program eliminasi filariasis, dan disisi lain pedoman baku sebagai rujukan kader kesehatan dan pasien atau keluarga dalam pengobatan dan pencegahan filariasis belum ada, dan walaupun sudah ada referensi lain, namun masih sulit dipahami oleh kader kesehatan dan pasien. Belum adanya prosedur tetap atau standar prosedur operasional yang baku juga patut menjadi pertimbangan. Hal ini sesuai dengan rangkuman hasil FGD terkait saran dari stakeholder kesehtan yaitu perlunya "Sosialisasi dan penyluhan 
kesehatan ke masyarakat perlu dilakukan secara lebih sering dan luas, perlunya deteksi dini penderita filariasis, pengobatan harus dilakukan sesegera mungkin secara intensif dan paripurna dengan melibatkan seluruh komponen masyarakat, perlu ada komitmen bersama antara pemerintah, dinas kesehatan, puskesmas, dan masyarakat".

Temuan tersebut tentunya patau menjadi catatatan karena sesuai dengan Peraturan Menteri Kesehatan Republik Indonesia nomor 94 tahun 2014 tentang penanggulangan

filariasis Penyelenggaraan Penanggulangan Filariasis dilaksanakan oleh Pemerintah dan Pemerintah Daerah dengan melibatkan peran serta masyarakat, melalui program pokok kegiatan surveilans kesehatan, penanganan penderita, pengendalian faktor risiko, dan program komunikasi, informasi, dan edukasi.

\section{KESIMPULAN DAN SARAN}

1. Faktor resiko filariasis terkait dengan hospes (pasien) adalah kuranganya pengetahuan pasien dan keluarga tentang pengobatan dan pencegahan penularan penyakit filariasis

2. Perilaku atau kebiasaan yang meningkatkan resiko terkena dan resiko penularan penyakit filariasis adalah pengendalian vektor nyamuk belum dilakukan dengan baik

3. Kondisi lingkungan rumah merupakan faktor resiko yang perlu diperhatikan oleh petugas kesehatan

4. Masih ditemukan adanya gap atau kesenjangan diantara stakeholder bidang kesehatan yang berperan dalam program eliminasi filariasis

5. Sektor pemerintahan desa sangat mendukung program penanggulangan penyakit filariasis

6. Masih ada pasien filariasis yang belum melakukan pengobatan filariasis secara tepat

7. Perlunya dibuat standar operating prosedur program eliminasi filariaisis

8. Perlu dipertimbangkan modul eliminasi filariasis yang sederhana dan aplikatif sebagai pegangan kader kesehatan dan keluarga pasien

9. Perlu dipertimbangkan program pendamping minum obat (PMO) pasien filariasis

10. Blueprint atau rencana jangka panjang eliminasi filariasis perlu dibuat Puskesmas sesuai dengan karakterisitik wilayah masing-masing

\section{DAFTAR RUJUKAN}

Wahyono TYM. Buletin Jendela Epidemiologi Filariasis di Indonesia. Pusat Data dan Surveilence Epidemiologi Kemenkes RI. 2010.

Depkes Republik Indonesia. Depkes infodatin-filariasis.pdf. 2010.

Astuti EP dkk. Media Litbangkes. Media Litbangkes. Analisis Perilaku Masyarakat Terhadap Kepatuhan Minum Obat Filariasis di Tiga Desa Kecamatan Majalaya Bandung Jawa Barat: 2014;24: 199-208.

Ipa M, Astuti EP, Hakim L, Fuadzy H. Analisis Cakupan Obat Massal Pencegahan Filariasis di Kabupaten Bandung dengan Pendekatan Model Sistem Dinamik Analysis of Filariasis Mass Drug Administration Coverage Through Dynamic System Model in Bandung Regency. 2016:31-38.

Krentel A, Fischer PU, Weil GJ. A 
Review of Factors That Influence Individual Compliance with Mass Drug Administration for Elimination of Lymphatic Filariasis. 2013;7(11). doi:10.1371/journal.pntd.0002447

Kumar A, Sachan P. Measuring impact on filarial infection status in a community study: Role of coverage of mass drug administration (MDA). 2014;31(2):225-229.

Pawenang M dan. Unnes Journal of Public Health. 2016;5(3):195-204.

Syuhada Y, W NE. Studi Kondisi Lingkungan Rumah dan Perilaku Masyarakat Sebagai Faktor Risiko Kejadian Filariasis di Kecamatan Buaran dan Tirto Kabupaten Pekalongan (Study Of Environmental And Behavioral As Risk Factor Of Filariasis In District Of Buaran And Tirto Pekalo. 2012;11(1):95-101.

Santi SM, Sabrian F, Karim D. Efektifitas Pendidikan Kesehatan Menggunakan Media Audiovisual Terhadap Perilaku Pencegahan Filariasis. 2014;1(2).

Sitorus H. Pengetahuan Tokoh Masyarakat dan Kader Kesehatan Tentang Program Eliminasi Filariasis Limfatik di Kecamatan Pemayung Kabupaten Batanghari Provinsi Jambi. 2016;8 (November):93-100.

Hapsari. Tentang Filariasis Limfatik Community Knowledge , Attitude And Practice About Lymphatic Filariasis In Madang Suku III Sub District, Oku. 2012.

Bharti AR, Nally JE, Ricaldi JN, et al. Reviews Leptospirosis : a zoonotic disease of global importance.
2003;3(December):757-771.

Masjoer A. Kapita Selekta Kedokteran.

III. Jakarta: Media Aesculapius Universitas Indonesia; 2000.

A. Arsunan Arsin. Epidemiologi Filarsiasis di Indonesia. (Asti Pratiwi D, ed.). Jakarta; 2016.

Offei M, Anto F. Bacteriology \& Parasitology Compliance to Mass Drug Administration Programme for Lymphatic Filariasis Elimination by Community Members and Volunteers in the Ahanta West District of Ghana. 2014;5(1):1-6. doi:10.4172/21559597.1000180

Kementerian Kesehatan. Filariasis : Menuju Indonesia Bebas Filariasis 2010. 2014.

Agustianingsih D. Praktik Pencegahan Filariasis. Jurnal Kesehatan Masyarakat. 2013;8(2):190-197.

Notoadmodjo S. Ilmu Perilaku Kesehatan. I. Jakarta: Rineka Cipta; 2010.

Rizky A. Analisis Faktor Resiko Kejadian Penyakit Filariasis. Unnes Journal of Public Health. 2014;3(1):1-12.

Setiani AO. Faktor Lingkungan dan Perilaku Masyarakat yang Berhubungan dengan Kejadian Filariasis di Kabupaten Sambas Environmental and Community Behavior Factor Associated With The Incidence of Filariasis in Sambas District. 2012;11(2):199207.

Colin G. Scanes dan Samia R. Toukhsati. Animal and Human Society. I. (Kristy Gomez, ed.). London; 2017.

Yusuf Muri A. Metode Penelitian Kuantitatif Kualitatif dan Penelitian Gabungan. I. Jakarta : Prenadamedia Grup;2014 